\section{Amygdalin Content in Kernels of Several Almond Cultivars Grown in Turkey}

\author{
Adnan Nurhan Yildirim ${ }^{1}$, Fatma Akinci-Yildirim, Mehmet Polat, \\ and Bekir Şan
}

Department of Horticulture, Agriculture Faculty, Suleyman Demirel University, Isparta, 32260 Turkey

\author{
Yılmaz Sesli \\ Ĕ̈irdir Fruit Research Station, Ĕ̆girdir, Isparta, Turkey
}

Additional index words. amygdalin, Amygdalus communis, cultivar

\begin{abstract}
Amygdalin is a bioactive compound used in the traditional treatment of some diseases, and it is toxic to humans and animals when it is consumed excessively. It is abundantly found in the kernels of almond cultivars, especially in bitter ones. In the study, the amygdalin contents of the kernels of 15 commercial almond cultivars (Prunus amygdalus L.) were determined by high-performance liquid chromatography (HPLC) for 2 consecutive years. The seeds of the cultivars were obtained from the Fruit Research Institute, Isparta, Turkey. Results indicated that amygdalin concentrations of the cultivars were significantly different $(P<0.05)$ for 2 years. The levels amygdalin ranged from $0.443 \mathrm{~g} \cdot \mathrm{kg}^{-1}$ to $1.866 \mathrm{~g} \cdot \mathrm{kg}^{-1}$ in 2008 and from $0.250 \mathrm{~g} \cdot \mathrm{kg}^{-1}$ to $2.200 \mathrm{~g} \cdot \mathrm{kg}^{-1}$ in 2009 . As the average of 2 years, the highest concentration of amygdalin was determined in 'Supernova' $\left(1.458 \mathrm{~g} \cdot \mathrm{kg}^{-1}\right)$ and the lowest concentration was determined in 'Masbovera' $\left(0.370 \mathrm{~g} \cdot \mathrm{kg}^{-1}\right)$.
\end{abstract}

Almond has been among the most important nutrients for human nourishment and health throughout the history of humanity owing to its high nutritional value (Calixto et al., 1981). In addition, some cyogenic glycosides such as prunasin and amygdalin contained in its fruit and leaf are used in pharmaceutics and medicine (Beyhan et al., 2011; Çelik and Balta, 2011; Esfahlan et al., 2010; Piscopo et al., 2010; Yildirim, 2007). Cyogenic glycosides are known as secondary metabolites and contained in $\approx 3000$ plant species from 110 families (Bolarinwa et al., 2014; Chassagne et al., 1996; Sanchez-Perez et al., 2008; Vetter, 2000). Of those, $\approx 75$ cyogenic glycosides have been identified (Chassagne et al., 1996). The amounts of cyogenic glycosides in plants not only depend on hereditary traits, but also are affected by the physiological and ecological factors that plants are exposed to (Vetter, 2000). The cyogenic glycosides found in various amounts in different plant organs such as root, shoot tip, bud, shell, and leaf play important roles in growth and development, graft compatibility, and defense mechanisms against pathogens in plants (Arrazola et al., 2012; Dicenta et al., 2002; Özgür, 1999; Sanchez-Perez et al., 2008; Treutter et al., 1990).

Amygdalin, known as either D-amygdalin (D-mandelonitrile- $\beta$-D-gentiobioside) or laetrile, is synthesize when the fenilalanin amino acid undergoes the reduction and oxidation

Received for publication 9 July 2014. Accepted for publication 7 Aug. 2014.

${ }^{1}$ To whom reprint requests should be addressed; e-mail adnanyildirim@sdu.edu.tr. reactions (Güleryüz and Aslantaş, 1997; Li et al., 1992). Overconsumption of seeds containing a high amount of cyanogenic glycosides might cause acute or chronic toxicity to human beings and animals because after amygdalin has been hydrolyzed through the action of $\beta$-glucosidase, it decomposes into benzaldehyde, glucose, and hydrocyanic acid, which has a toxic and lethal effect on the human health (Ferrara et al., 2010; Güleryüz and Aslantaş, 1997; Lee et al., 2013; Li et al., 1992; Sanchez-Perez et al., 2008; Yada et al., 2011; Yildirim and Askin, 2010). Despite this deleterious effect of the amygdalin glycoside on the human health, it has advantages as well. It has been used in the treatment of cancer with the names "laetrile" and "vitamin $\mathrm{B}_{17}$ " in recent years (Femenia et al., 1995; Frison and Sporns, 2002; Yildirim and Askin, 2010) along with the treatment of diseases such as asthma, bronchitis, migraine, leprosy, and diabetes (Bolarinwa et al., 2014; Halenar et al., 2013; Zhou et al., 2012). Nevertheless, the cancer-preventive efficiency of laetrile has not been proved yet, and it is reported that no permission could be obtained from the U.S. Food and Drug Administration for the use of vitamin B17 as a drug in the treatment of patients (Asma and Misirli, 2007). Amygdalin is found in both many species of family Rosaceae (particularly in the species of subfamilies Prunoideae and Maloideae) and the species of families Leguminosae, Gramineae, Araceae, Compositae, and Euphorbiaceae (Ferrara et al., 2010). Amygdalin is widely found, especially in the seeds of the plant. It is abundant in the seeds of fruit species such as almond, apricot, and plum in subfamily Prunoideae (Bolarinwa et al., 2014). Amygdalin causes bitterness in seeds, and this trait displays monogenic inheritance. The almonds whose seeds are consumed are grouped as bitter, light bitter, and sweet according to their amygdalin contents by consumers and growers. In the limited number of previous studies, it is reported that bitter or sweet almond cultivars contain different amounts of amygdalin and that there is extensive variation between subspecies and cultivars. However, very few studies were performed regarding the amygdalin contents of commercially grown cultivars (Arrazola et al., 2012; Dicenta et al., 2002; Ferrara et al., 2010; Kester et al., 1990; Lee et al., 2013; Yildirim et al., 2010). The objective of this study was to determine the amygdalin contents of the seeds of 15 commercial almond cultivars grown and exhibiting light bitter and sweet traits under the ecological conditions of Isparta, Turkey. The data would provide important information on the chemical classification of these cultivars as well as taste.

\section{Materials and Methods}

This study was conducted in 2008 and 2009. In the study, the seed samples of 15 almond cultivars planted in 2003 were obtained from the trees in the almond cultivar collection orchard located in the Eğirdir Fruit Research Station in Isparta province of Turkey. The orchard was irrigated by the drip irrigation method consisting of two lateral lines per tree row with continuous dripper spacing of $50 \mathrm{~cm}$. All fertilizers were dissolved and injected into the irrigation system. The orchard was fertilized with the standard as ammonium nitrate, potassium sulphate, phosphoric acid, zinc sulphate, and borax. The cultivars including Cristomorto, Desmayo Largueta, Ferraduel, Ferragnes, Ferrastar, Glorieta, Lauranne, Masbovera, Nonpareil, Picantili, Sonora, Supernova, Texas, Tuono, and Yaltinski grafted on almond seedling rootstocks were used in the study. Approximately $1 \mathrm{~kg}$ almond fruits were taken from different parts of the trees. The fruits were dried for $20 \mathrm{~d}$ at room temperature and cracked out by hand. Five hundred grams of almond kernel from each cultivar were ground to powder and the powder samples were placed in plastic bags. Samples were frozen and kept at $-80^{\circ} \mathrm{C}$ until extraction.

Amygdalin analysis. Two grams of the samples from each cultivar seed were extracted with $100 \mathrm{~mL}$ of methanol in the Soxhlet equipment for $6 \mathrm{~h}$. Methanol was evaporated at $40{ }^{\circ} \mathrm{C}$ in the evaporator. The residue was dissolved in $10 \mathrm{~mL}$ of mobile phase $\left(\mathrm{CH}_{3} \mathrm{CN}: \mathrm{H}_{2} \mathrm{O}\right)$. The sample was passed through the Sep-Pak C18 cartridge (Agilent Inc., USA) preconditioned with $\mathrm{CH}_{3} \mathrm{CN}$ and $\mathrm{H}_{2} \mathrm{O}$. The solution was diluted 500 times, and $10 \mu \mathrm{L}$ of the sample was injected into the HPLC (Gomez et al., 1998). Conditions for the HPLC were: detector: SPD-10AVvp diode array detector $(\lambda \max =238 \mathrm{~nm})$, system controller: SCL-10 Avp. Pump: LC-6AD, column: ACE 5-C18 
$(250 \times 4.6 \mathrm{~mm}, 5 \mu \mathrm{m})$, mobile phase: $\mathrm{CH}_{3} \mathrm{CN}: \mathrm{H}_{2} \mathrm{O}(75: 25, \mathrm{v} / \mathrm{v})$, flow rate: 0.9 $\mathrm{mL} \cdot \mathrm{min}^{-1}$, injection volume: $20 \mu \mathrm{L}$, column temperature: $25^{\circ} \mathrm{C}$. Amygdalin (Sigma-Aldrich Inc., USA) was used as a standard. Concentrations of amygdalin were determined by correlation of their HPLC peak areas to their calibration curves. The concentrations were expressed as $\mathrm{g} \cdot \mathrm{kg}^{-1}$. All chemical analyses were carried out in triplicates.

Data were subjected to analysis of variance (ANOVA) using Minitab 13 statistical software (Minitab Inc.). The means were separated by Duncan's multiple range test $(P<0.05)$.

\section{Results and Discussion}

The results of the ANOVA are presented in Table 1 and the means of the amygdalin contents of the studied almond cultivars are presented in Table 2. The ANOVA indicated that the cultivars, the years, and the "cultivar $\times$ year" interaction were found to be statistically significant at $P<0.01$ with regard to amygdalin content (Table 1). The results obtained from the research showed that the amygdalin contents of the cultivars except for 'Picantili' significantly $(P<0.05)$ varied by year. In 2008, the highest amygdalin content was detected in cultivar Tuono $\left(1.866 \mathrm{~g} \cdot \mathrm{kg}^{-1}\right)$ followed by cultivars Ferraduel $\left(1.380 \mathrm{~g} \cdot \mathrm{kg}^{-1}\right)$, Desmayo Largueta $\left(1.280 \mathrm{~g} \cdot \mathrm{kg}^{-1}\right)$, and Sonora $\left(1.030 \mathrm{~g} \cdot \mathrm{kg}^{-1}\right)$, respectively. The lowest value in this year was found in cultivar Picantili ( 0.443 g. $\left.\mathrm{kg}^{-1}\right)$. In 2009, the highest amygdalin content was detected in cultivar Supernova $(2.200$ $\mathrm{g} \cdot \mathrm{kg}^{-1}$ ) followed by cultivars Cristomorto (1.916 g. $\left.\mathrm{kg}^{-1}\right)$, Lauranne (1.756 $\left.\mathrm{g} \cdot \mathrm{kg}^{-1}\right)$, and

Table 1. The results of variance analysis for year, cultivar, and year $\times$ cultivar interaction.

\begin{tabular}{lrc}
\hline $\begin{array}{l}\text { Source of } \\
\text { variation }\end{array}$ & df & $\begin{array}{c}\text { Mean } \\
\text { square }\end{array}$ \\
\hline Year & 1 & $0.86730^{*}$ \\
Cultivars & 14 & $0.99706^{*}$ \\
Year $\times$ cultivars & 14 & $0.78032^{*}$ \\
Error & 58 & 0.00220 \\
\hline
\end{tabular}

*Significant at $P<0.01$.
Ferragnes $\left(1.660 \mathrm{~g} \cdot \mathrm{kg}^{-1}\right)$, respectively. Cultivar Masbovera $\left(0.250 \mathrm{~g} \cdot \mathrm{kg}^{-1}\right)$ showed the lowest amygdalin content (Table 2).

In terms of the average of both years, extensive variations were observed among the cultivars. The highest amygdalin content was detected in cultivar Supernova (1.458 $\left.\mathrm{g} \cdot \mathrm{kg}^{-1}\right)$ followed by Lauranne $\left(1.385 \mathrm{~g} \cdot \mathrm{kg}^{-1}\right)$, Ferraduel (1.336 g. $\left.\mathrm{kg}^{-1}\right)$, Tuono (1.321 $\left.\mathrm{g} \cdot \mathrm{kg}^{-1}\right)$, and Cristomorto $\left(1.295 \mathrm{~g} \cdot \mathrm{kg}^{-1}\right)$, respectively. On the other hand, 'Masbovera' had the lowest content $\left(0.370 \mathrm{~g} \cdot \mathrm{kg}^{-1}\right)$ followed by 'Picantili' (0.441 g. $\left.\mathrm{kg}^{-1}\right)$ and 'Nonpariel' $\left(0.470 \mathrm{~g} \cdot \mathrm{kg}^{-1}\right)$. These results are in agreement with the results reported by Kester et al. (1990). Nevertheless, they were higher than the values that Ferrara et al. (2010) reported for cultivars Cristomorto, Rachele Grande, Glorieta, Ne Plus Ultra, Nonpareil, Clellaston, J. Prolific $\left(0 \mathrm{~g} \cdot \mathrm{kg}^{-1}\right)$ and Fragiulio Grande $\left(0.000158 \mathrm{~g} \cdot \mathrm{kg}^{-1}\right)$. Additionally, they were also higher than the values obtained from the almond genotypes by Yildirim et al. (2010). Furthermore, they resembled the results obtained from a study on sweet apricot cultivars (8.61 $\mathrm{g} \cdot \mathrm{kg}^{-1}$ on average) (Yildirim and Askin, 2010). These differences are thought to be the result of the differences in cultivars, rootstocks, fruit maturity, and growing and environmental conditions (Bolarinwa et al., 2014; Sanchez-Perez et al., 2008). Moreover, besides the genetic features of cultivars, the physiological and ecological factors to which plants are exposed also have effects on amygdalin content (Bolarinwa et al., 2014; Güleryüz and Aslantaş 1997; Vetter, 2000; Yildirim et al., 2010; Yildirim and Askin, 2010). Lee et al. (2013) also reported that the amygdalin contents of the cultivars varied according to different cultivation regions.

Of the cultivars in our study, nine are identified as sweet and six as light bitter (Anonymous, 2014; Arrazola et al., 2012; Dicenta et al., 2007; Ferrara et al., 2010; Lee et al., 2013; Sanchez-Perez et al., 2008). The research results demonstrated that light bitter almond cultivars generally had higher amygdalin contents than the sweet cultivars (Table 2). Likewise, Lee et al. (2013), who determined the amygdalin contents of bitter, semibitter, and sweet almonds, also reported that bitter almonds had higher amygdalin contents as compared with sweet almonds. Nevertheless, in the study, the cultivars Ferraduel and Ferragnes, reported as sweet almonds, contained amygdalin as much as the light bitter cultivars. It is likely that there are other factors that suppress slight bitterness here. In the study, it was also determined that the light bitter cultivars had amygdalin contents as much as the sweet cultivars in some years (Table 2). It is seen that the cultivar effect is significant here. Likewise, Dicenta et al. (2007), who explored the genetic control of the trait of bitterness, expressed that bitterness was recessive; however, heterozygous individuals were either sweet or light bitter and that this might vary by year. In addition, the authors expressed that some other factors might also be effective on the occurrence of bitterness. Furthermore, Lee et al. (2013) reported that normally sweet almonds could be distinguished easily from bitter almonds as a result of their amygdalin contents; however, they could not be distinguished from light bitter almonds. The same researchers determined that bitter, light bitter, and sweet almonds contained on average $40.06 \mathrm{~g} \cdot \mathrm{kg}^{-1}, 0.99$ $\mathrm{g} \cdot \mathrm{kg}^{-1}$, and $0.06 \mathrm{~g} \cdot \mathrm{kg}^{-1}$ of amygdalin, respectively. Likewise, in this study we have observed that the light bitter almonds contained $1.131 \mathrm{~g} \cdot \mathrm{kg}^{-1}$ of amygdalin on average, whereas the sweet almonds contained 0.734 $\mathrm{g} \cdot \mathrm{kg}^{-1}$ of amygdalin on average. These results might help to classify cultivars based on their amygdalin contents.

In conclusion, extensive genetic variation in amygdalin contents was found among the cultivars. In terms of the average of the years, the highest amygdalin content was obtained from the light bitter cultivar Supernova, but the lowest amygdalin content was obtained from the sweet cultivar Masbovera. Besides, differences in the amygdalin contents of the cultivars were also observed among years.
Table 2. Amygdalin content of almond cultivars $\left(\mathrm{g} \cdot \mathrm{kg}^{-1}\right)$.

\begin{tabular}{|c|c|c|c|c|c|}
\hline \multirow[b]{2}{*}{ Cultivar } & \multicolumn{4}{|c|}{ Years } & \multirow[b]{2}{*}{ Avg } \\
\hline & 2008 & & 2009 & & \\
\hline Cristomorto (light bitter) & $0.673 \pm 0.0577$ & deB & $1.916 \pm 0.1670$ & $\mathrm{bA}$ & 1.295 \\
\hline D. Largueta (light bitter) & $1.280 \pm 0.0289$ & bA & $0.703 \pm 0.0954$ & $f g B$ & 0.991 \\
\hline Ferraduel (sweet) & $1.380 \pm 0.0208$ & bA & $1.293 \pm 0.0493$ & $\mathrm{~dB}$ & 1.336 \\
\hline Ferragnes (sweet) & $0.510 \pm 0.0400$ & fgB & $1.660 \pm 0.0500$ & $\mathrm{cA}$ & 1.085 \\
\hline Ferrastar (light bitter) & $0.523 \pm 0.0985$ & $\mathrm{fgB}$ & $1.100 \pm 0.0503$ & $\mathrm{eA}$ & 0.811 \\
\hline Glorieta (sweet) & $0.523 \pm 0.0513$ & fgA & $0.456 \pm 0.0361$ & $\mathrm{hB}$ & 0.490 \\
\hline Lauranne (sweet) & $1.013 \pm 0.0321$ & $\mathrm{cB}$ & $1.756 \pm 0.0346$ & $\mathrm{cA}$ & 1.385 \\
\hline Masbovera (sweet) & $0.490 \pm 0.0306$ & $\mathrm{fgB}$ & $0.250 \pm 0.1002$ & $1 \mathrm{~A}$ & 0.370 \\
\hline Nonpareil (sweet) & $0.593 \pm 0.0907$ & efA & $0.346 \pm 0.1115$ & $h_{1 B}$ & 0.470 \\
\hline Picantili (sweet) & $0.443 \pm 0.0624$ & G & $0.440 \pm 0.0557$ & $\mathrm{~h}$ & 0.441 \\
\hline Sonora (light bitter) & $1.030 \pm 0.0473$ & $\mathrm{cA}$ & $0.800 \pm 0.1102$ & $\mathrm{fB}$ & 0.915 \\
\hline Supernova (light bitter) & $0.716 \pm 0.0608$ & $\mathrm{~dB}$ & $2.200 \pm 0.1217$ & $\mathrm{aA}$ & 1.458 \\
\hline Texas (sweet) & $0.563 \pm 0.0603$ & efgA & $0.420 \pm 0.0416$ & $\mathrm{hB}$ & 0.491 \\
\hline Tuono (light bitter) & $1.866 \pm 0.0854$ & $\mathrm{aA}$ & $0.776 \pm 0.0513$ & $\mathrm{fB}$ & 1.321 \\
\hline Yaltinski (sweet) & $0.463 \pm 0.0451$ & $\mathrm{gB}$ & $0.626 \pm 0.1582$ & $\mathrm{gA}$ & 0.545 \\
\hline Average (year) & 0.804 & & 0.983 & & \\
\hline
\end{tabular}

Each value is expressed as mean \pm SD; means followed by different upper case letters in the columns are significantly different $(P<0.05)$. Each value is expressed as mean followed by different lower case letters in the columns are significantly different $(P<0.05)$.

\section{Literature Cited}

Anonymous. 2014. European commission, community programme on genetic resources in agriculture. 11 Apr. 2014. <http://safenut.casaccia. enea.it/db/accessions $>$.

Arrazola, G., P.R. Sanchez, F. Dicenta, and N. Grane. 2012. Content of the cyanogenic glucoside amygdalin in almond seeds related to the bitterness genotype. Agronomia Colombiana 30:260-265.

Asma, B.M. and A. Misirli. 2007. Apricot seed. Hasad Bitkisel Üretim 22:55-58.

Beyhan, Ö., M. Aktaş, N. Yılmaz, N. Şimşek, and R. Gerçekçioğlu. 2011. Determination of fatty acid compositions of some important almond (Prunus amygdalus L.) varieties selected from Tokat province and Eagean region of Turkey. Journal of Medicinal Plants Research 5:4907-4911.

Bolarinwa, I.F., C. Orfila, and M.R.A. Morgan. 2014. Amygdalin content of seeds, kernels and food products commercially-available in the UK. Food Chem. 152:133-139. 
Calixto, F.S., M. Bauza, F. Martinez de Toda, and A. Argamenteria. 1981. Amino acids, sugars and inorganic elements in the sweet almond (Prunus amygdalus). J. Agr. Food Chem. 29:509-511.

Çelik, F. and M.F. Balta. 2011. Kernel fatty acid composition of Turkish almond (Prunus dulcis) genotypes: A regional comparison. J. Food Agr. Environ. 9:171-174.

Chassagne, D., J.C. Crouzet, C.L. Bayonove, and R.L. Baumes. 1996. Identification and quantification of passion fruit cyanogenic glycosides. J. Agr. Food Chem 44:3817-3820.

Dicenta, F., P. Martinez-Gomez, N. Grane, M.L. Martin, A. Leon, J.A. Canovas, and V. Berenguer. 2002. Relationship between cyanogenic compounds in kernels, leaves and roots of sweet and bitter kernelled almonds. J. Agr. Food Chem. 50:2149-2152.

Dicenta, F., E. Ortega, and P. Martinez-Gomez. 2007. Use of recessive homozygous genotypes to assess the genetic control of kernel bitterness in almond. Euphytica 153:221-225.

Esfahlan, A.J., R. Jamei, and R.J. Esfahlan. 2010. The importance of almond (Prunus amygdalus L.) and its by-products. Food Chem. 120:349-360.

Femenia, A., C. Rossello, A. Mulet, and J. Canellas. 1995. Chemical composition of bitter and sweet apricot kernels. J. Agr. Food Chem. 43:356361.

Ferrara, G., P. Maggio, and M.D.R. Pizzigallo. 2010. Cyanogenic d-amygdalin contents of the kernels of cultivated almonds and wild Amygdalus webbii Spach. J. Hort. Sci. Biotechnol. 85:410-414.

Frison, S. and P. Sporns. 2002. Variation in the flavonol glycoside composition of almond seedcoats as determined by MALDI-TOF mass spectrometry. J. Agr. Food Chem. 50:6818-6822.

Gomez, E., L. Burgos, C. Soriano, and J. Marin. 1998. Amygdalin content in the seeds of several apricot cultivars. J. Sci. Food Agr. 77:184-186

Güleryüz, M. and R. Aslantaş. 1997. The importance of glycoside amygdalin, inheritance, biosynthesis and hydrolyses. Atatürk University Journal of Agriculture Faculty 28:656-661.

Halenar, M., M. Medvedova, N. Maruniakova, and A. Kolesarova. 2013. Amygdalin and its effects on animal cells. Journal of Microbiology, Biotechnology and Food Sciences 2:1414-1423.

Kester, D.E., T.M. Gradziel, and C. Grasselly. 1990. Almonds (Prunus), p. 699-758. In Moor, J.N. and J.R. Ballington (eds.). Genetic resources of temperate fruit and nut crop II. ISHS, Wageningen, The Netherlands.

Lee, J., G. Zhang, E. Wood, C.R. Castillo, and A.E. Mitchell. 2013. Quantification of amygdalin in nonbitter, semibitter, and bitter almonds (Prunus dulcis) by UHPLC-(ESI) QqQ MS/MS. J. Agr. Food Chem. 61:7754-7759.

Li, C.P., E. Swain, and J.E. Poulton. 1992. Prunus serotina amygdalin hydrolase and prunasin hydrolase. Plant Physiol. 100:282-290.

Özgür, M. 1999. Determination of phenolic compounds in almond hybrids resistant and susceptible to Psedomonas amygdali. Master's thesis, Ege University, Graduate School of Natural and Applied Science, Horticulture Science, İzmir, Turkey.

Piscopo, A., F.V. Romeo, B. Petrovicova, and M. Poiana. 2010. Effect of the harvest time on kernel quality of several almond varieties
[Prunus dulcis (Mill.) D.A. Webb]. Sci. Hort. 125:41-46.

Sanchez-Perez, R., K. Jorgensen, C.E. Olsen, F. Dicenta, and B.L. Moller. 2008. Bitterness in almond. Plant Physiol. 146:1040-1052.

Treutter, D., P.P. Schimid, and W. Feucht. 1990. Wall-bound phenols and peroxidase activity in shoots of Prunus. I. Isolation and identification of phenolic acids. Gartenbauwissenschaft 55: 69-72.

Vetter, J. 2000. Plant cyanogenic glycosides. Toxicon 38:11-36.

Yada, S., K. Lapsley, and G. Huang. 2011. A review of composition studies of cultivated almonds: Macronutrients and micronutrients. Journal of Food and Analysis 24:469-480.

Yildirim, A.N. 2007. The almond selection in Isparta Region. $\mathrm{PhD}$ thesis, Adnan Menderes University, Graduate School of Natural and Applied Science, Horticulture Science, Aydın, Turkey.

Yildirim, A.N., B. San, F. Koyuncu, and F. Yıldırım. 2010. Variability of phenolics, $\alpha$-tocopherol and amygdalin contents of selected almond (Prunus amygdalus Batsch.) genotypes. J. Food Agr. Environ. 8:76-79.

Yildirim, F.A. and M.A. Askin. 2010. Variability of amygdalin content in seeds of sweet and bitter apricot cultivars in Turkey. Afr. J. Biotechnol. 9:6522-6524.

Zhou, C., L. Qian, H. Ma, X. Yu, Y. Zhang, W. Qu, X. Zhang, and W. Xia. 2012. Enhancement of amygdalin activated with $\beta$-D-glucosidase on HepG2 cells proliferation and apoptosis. Carbohydr. Polym. 90:516-523. 